TAPROBANICA, ISSN 1800-427X. April, 2009. Vol. 01, No. 01: pp. 55-62, pls 8.

(C) Taprobanica Nature Conservation Society, 146, Kendalanda, Homagama, Sri Lanka.

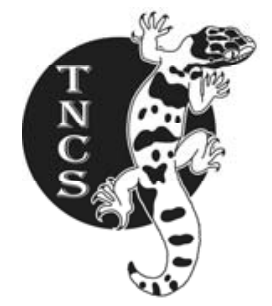

\title{
THE WILD BUFFALO OF SRI LANKA
}

Submitted: 20 February 2009, Accepted: 26 February 2009

Colin Groves ${ }^{1}$ and Jayantha Jayawardene ${ }^{2}$

\footnotetext{
${ }^{1}$ School of Archaeology \& Anthropology, Australian National University, Canberra, ACT 0200, Australia

${ }^{2}$ Biodiversity and Elephant Conservation Trust, 615/32, Rajagiriya Gardens, Rajagiriya, Sri Lanka.

${ }^{1}$ Corresponding author: colin.groves@anu.edu.au
}

\begin{abstract}
Buffaloes live wild in many areas in Sri Lanka, but it is controversial whether any of them are genuinely wild, or whether they are all feral. We investigated this question by observation of living buffaloes in Yala National Park, and measurement of available cranial material. We conclude that there is indeed an indigenous wild buffalo in Sri Lanka. Steps should be taken to ensure its genetic integrity.
\end{abstract}

Key Words: Buffalo, Bubalus arnee migona, Sri Lanka, Yala, cranial capacity.

\section{Introduction}

\section{Does Sri Lanka have a native wild buffalo?}

$19^{\text {th }}$-century authors, such as Kelaart, listed the Sri Lankan wild buffalo as a genuinely wild animal, and Deraniyagala (1952, amplified in 1953) described it as a separate subspecies. More recent authors, however, have either assumed it to be of feral origin (Ellerman \& Morrison-Scott, 1951; Phillips, 1980), or have suspended judgment.

Eisenberg \& McKay (1970) wrote "status of feral population is debatable"; while Ashby \& Santiapillai (1983) remarked, "Given the distinctiveness of the free-living form in Sri Lanka, the balance of probability is that it should be regarded as wild rather than feral but no conclusive answer can be given on the present evidence”.

Wherever there are wild buffalo, there is a danger of interbreeding with local domestic stock. The truly wild buffalo of the Asian mainland are all notably larger than any local domestic buffaloes, and it would not be expected that feral or mixed buffaloes would offer them much competition; consequently, feral buffaloes would have little chance of surviving for long, and gene-flow would be almost entirely one-way (from wild to domestic). If on the other hand the genuine wild stock becomes numerically depleted, competition would be relaxed, and there 